\section{Oversiktlig innføring i hudsykdommer}

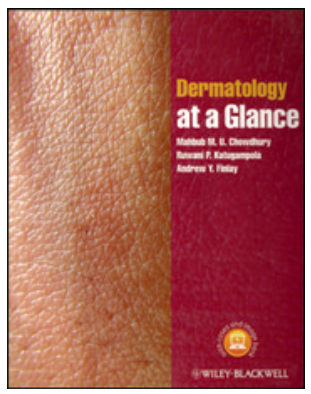

\author{
Mahbub M. U. Chowdhury, \\ Ruwani P. Katugampola, Andrew Y. Finlay \\ Dermatology at a glance \\ $111 \mathrm{~s}, \mathrm{tab}, \mathrm{ill}$. Chichester: Wiley-Blackwell, \\ 2013. Pris GBP 25 \\ ISBN 978-0-470-65673-0
}

Boken er en kortfattet lærebok i dermatologi rettet mot medisinstudenter. Den inngår i den britiske At a glance-serien som har som ambisjon å dekke medisinsk kjernepensum på en lettfattelig og tilgjengelig måte.

Bidragsyterne legger stor vekt på bilder, illustrasjoner og tabeller, og presenterer mye viktig innhold i rammer og i listeform. De 46 små kapitlene består hvert av to sider der den ene siden utgjøres av kliniske bilder og rammer/lister, mens motstående side fylles av løpende tekst. Denne siden avsluttes av en ramme med kjernepunkter og en ramme med advarsler mot å overse viktige symptomer eller tegn. Til slutt i boken er det en quiz med dermatologiske bilder.

De første kapitlene er viet evidensbasert dermatologi og viktige nettsider og kildebruk, noe som gjenspeiler dagens måte å søke oppdatert kunnskap på. Dessuten veileder disse sidene leserne til kilder for utdypende lesing. Videre finnes innledende kapitler om livskvalitet og sosioøkonomisk betydning av dermatologiske sykdommer, et aspekt ved det medisinske fagfeltet som har fătt økende oppmerksomhet i løpet av de siste tiårene. Pasientens opplevelse av livskvalitet er blant annet en målbar parameter som, ifølge retningslinjene, har avgjørende betydning for valg av behandling ved viktige hudsykdommer som psoriasis. Innledningsvis er det også rikt illustrerte innføringer i viktige prosedyrer og behandlingsprinsipper.

De sykdomsspesifikke kapitlene er dels inndelt etter tradisjonelt mønster viet de enkelte dermatologiske sykdommene og sykdomsgruppene, dels etter et mer symptomorientert, eller pasientorientert, mønster. For eksempel er det kapitler om «rødt fjes», «håndeksem og yrke», «aldrende hud» og «barn med utslett». Disse kapitlene gir en problemorientert og klinisk spennende tilnærming til den dermatologiske pasienten, men er også krevende, både didaktisk og redaksjonelt siden en del tilstander på denne måten må nevnes flere steder.

De sykdomsspesifikke kapitlene er godt illustrert med bilder og tekstrammer, men teksten lider stedvis under knapphet på plass som følge av den fastlagte layouten. Således blir det i liten grad plass til utdypende forklaringer om patogenese, diagnostikk og valg av behandling. Særlig det sistnevnte blir enkelte steder noe tynt, blant annet listes systemisk psoriasisbehandling uten kommentar om virkningsmekanisme, bivirkninger eller forsiktighetsregler. For bruk av lokale steroider ved atopisk dermatitt legger forfatterne mer vekt på å advare mot steroidbivirkninger enn å gi trygghet for korrekt bruk. I omtalen av dermatofyttinfeksjoner kommer det ikke klart frem at tinea capitis alltid krever systemisk antifungal behandling.

Styrken - og svakheten - ligger derfor i den forutsigbare oppbyggingen og presentasjonen av stoffet med gode kliniske bilder og utheving av kjernebudskap i tilknytning til disse, men av og til på bekostning av tekst, som enkelte steder blir så kortfattet at budskapet ikke kommer helt frem. Likevel vil boken være et greit alternativ til dagens pensumlitteratur for de fleste medisinstudenter, særlig hvis den kombineres med oversiktsartikler og retningslinjer, slik forfatterne foreslår. De problembaserte kapitlene vil også kunne ha praktisk nytteverdi for praktiserende leger som møter pasienter med hudsykdommer i hverdagen.

\section{Artig bok om «soft skills» for leger}

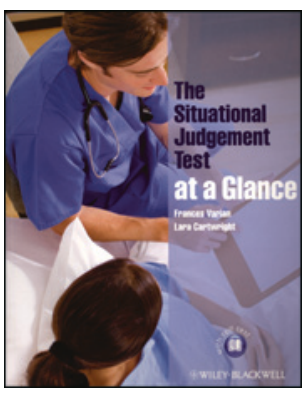

Frances Varian, Lara Cartwright

The situational judgement test at a glance

91 s, ill. Chichester: Wiley-Blackwell, 2012. Pris GBP 23

ISBN 978-1-1184-9098-3

Som en del av tilsettingsprosessen for turnusleger i Storbritannia blir de kommende legene blant annet evaluert med en «situational judgement test». Her tester man ikke kliniske ferdigheter, men snarere hvordan man håndterer vanskelige arbeidssituasjoner. Det er denne testen som forfatterne av denne teksten tar sikte på å gi studentene en innføring i.

Forfatterne dekker emner som profesjonalitet, etikk, kommunikasjon og pasientsentrert medisin, og boken er bygd opp med små teoribolker og kommentarer fra både turnusleger og andre. Det er flere gode eksempler, og avslutningsvis er det spørsmål som tester om studentene har fått med seg poengene. Den er lettlest og kortfattet, og inneholder en rekke gode huskeregler og tips for å håndtere en overveldende klinisk hverdag.

Elementene forfatterne tar opp, er viktige, men ettersom målgruppen er et engelsk publikum vil nok en del av situasjonene, og ikke minst lovverket, kunne avvike noe fra en norsk hverdag. En slik bok med norske eksempler burde imidlertid vært obligatorisk for alle vordende turnusleger. En «situational judgmenet test» burde også bestås av både turnusleger og leger i spesialisering for å oppnå godkjenning.

\section{Jo-Inge Myhre}

Medisinsk avdeling

Sykehuset Innlandet, Divisjon Gjøvik 